International Journal of Agriculture, Environment and Bioresearch

Vol. 4, No. 05; 2019

ISSN: $2456-8643$

\title{
COMPARATIVE ANALYSIS OF NATURAL FALLOWS AND ACACIA MANGIUM FALLOWS IN THE CLASSIFIED FOREST OF ANGUEDEDOU (COTE D'IVOIRE)
}

\author{
KOUADIO Kouassi Richard \\ Laboratory of Botany, UFR of the Sciences of the Nature, University Nangui Abrogoua, Abidjan (Ivory Coast), 02 \\ BP 801 Abidjan 02 \\ http://doi.org/10.35410/IJAEB.2019.4447
}

\begin{abstract}
Like the exotic plant species of Côte d'Ivoire, the question of harmfulness or usefulness of Acacia mangium needs to be clarified. Based on comparisons of floras of natural fallows and Acacia mangium fallows, the purpose of this study was to assess the contribution of natural fallows and improved fallows in Acacia mangium to the improvement of plant biodiversity. The parameters considered in this work were floristic diversity and composition, plant succession and floral similarity. Concerning floristic richness, Acacia mangium fallows was more productive than natural fallows. In addition, the morphological analysis of the species encountered shows an abundance of woody species in the Acacia mangium fallows and those of herbaceous species in the natural fallows.
\end{abstract}

Keywords: Côte d'Ivoire, exotiques, Acacia mangium, jachères, comparaisons.

\section{INTRODUCTION}

The current problem of arable land degradation and availability need fallow lands using. In these agricultural systems, the cleared lands are abandoned over a period of time in order to restore soil fertility or provide ecosystem services (Kouadio, 2018). Except the the biological potentials restoration of the natural environments they support, fallow land can be usefulls in plant succession and ecological resilience of ecosystems (Serpantié \& Devineau, 1991). In the context of sustainable development, these traditional practices remain important because they are used by populations like a means of environment preservation (Juhé-Beaulaton, 2010).

However, the services rendered by this farming technique are limited by the shortening of the fallow period, because of the agricultural pressure and population explosion that induce high land demands (Floret \& Pontanier, 2000 ; Djaha \& al., 2009). Depending on the method used, there is natural fallows and improved fallows which are characterised by the introduction of nitrogen-fixing species or not. In order to developing strategies and actions for sustainable forest management, Acacia mangium was introduced in areas of dense wet forest, particular in

Anguédédou, Dabou, La Mé and Sangoué (N'Guessan, 1991 ; Allou \& al., 2001 ; N'Goran \& al., 2002). Commonly used as cultivation methods, fallow lands can be employed as forest ecosystems restoration (Kouadio, 2018). 
This study aim to assess the contribution of these fallow lands types in terms of biodiversity. It is specifically a question of comparing plant succession and floristic diversity in natural fallow and improved fallow (in Acacia mangium).

\section{MATERIALS AND METHODS}

We exploited two types of fallow, including natural fallows and artificial fallows with Acacia mangium. We selected three age classes for each type of fallow, for a total of six (06) fallows (Table 1). A floristic survey was carried out in each fallow. The data were collected using the surface survey method supplemented by itinerant surveys. The survey size was $1750 \mathrm{~m} 2$. The nomenclature of flora is adopted according to the Angiosperm Phylogeny Group IV (2016). The comparative analysis of fallows floras concerned the floristic composition and diversity, plant succession and hierarchical classification of the surveys according to Sorensen index. The morphological types of the species were determined based on our field observations. These include ligneous, lianas and herbaceous species.

Table 1 : summary table of fallow lands used

Type of fallow land

\begin{tabular}{|lll|}
\hline Age class & Natural & with Acacia mangium \\
\hline class 1 $(0-3$ years $)$ & NatAg1 & ManAg1 \\
\hline class 2 (4-7 years) & NatAg2 & ManAg2 \\
\hline class 3 (8-13 years) & NatAg3 & ManAg3 \\
\hline
\end{tabular}

We used PAST software to calculate floristic diversity parameters diversity (Shannon index and equitability index). There are expressed by the following equations :

$\mathrm{H}=-(\mathrm{ni} / \mathrm{N}) \log 2(\mathrm{ni} / \mathrm{N})$ and $\mathrm{J}^{\prime}=\mathrm{H} / \ln \mathrm{S}$

H_Shannon index; ni_species individuals number ; N_all species individuals number ; S_total species number of a biotope.

Averages of floristic parameters were compared using an analysis of variance (Anova). The level of significance chosen for these analyses was 5\% (p-value 0.05). A Tukey test was realised to classify and discern value groups when the difference was significant. These tests were carried out using the XLSTAT software.

\section{RESULTS}

\section{Floristic richness and diversity}

In natural fallows, we get one hundred and twenty-three (123) species classified in ninety-five (95) genera and occured in forty (40) families. The fallows with Acacia mangium contain one hundred and forty-five (145) species distributed in one hundred and eleven (111) genera and arranged in fifty-two (52) families. The floras of natural fallows and Acacia mangium fallows 
are diversified and homogeneous. Indeed, the Shannon index and equitability index are relatively important in two types of biotopes (Table 2).

Statistical analysis of the values of these diversity parameters shows statistical differences between them (Table 2). Three groups of biotopes stand out for the Shannon index. The first group consists of the highest value of fallow land, NatAg3 (2.91 \pm 0.12$)$. In the second group, there are plots with mean values of Shannon index. These plots are NatAg1 (2.74 \pm 0.12$),$ NatAg2 (2.69 \pm 0.12$), \operatorname{ManAg} 2(2.83 \pm 0.12)$ and $\operatorname{ManAg} 3(2.66 \pm 0.12)$. The third and final group contains ManAg1, which is the lowest Shannon index (2.33 \pm 0.12$)$. Three groups of fallow land are also observed concerning equitability index (Table 2).

Table 2 : Floristic diversity in fallows studied

\begin{tabular}{|lll|}
\hline Biotopes & Shannon Index $\left(\mathrm{H}^{\prime}\right)$ & Equitability Index $\left(\mathrm{J}^{\prime}\right)$ \\
\hline NatAg1 & $2.74 \pm 0.13 \mathrm{ab}$ & $\mathbf{0 , 9 6} \pm \mathbf{0 . 0 2 a}$ \\
\hline NatAg2 & $2.69 \pm 0.19 \mathrm{ab}$ & $0,95 \pm 0.01 \mathrm{ab}$ \\
\hline NatAg3 & $\mathbf{2 . 9 1} \pm \mathbf{0 . 2 9 a}$ & $0,95 \pm 0.01 \mathrm{ab}$ \\
\hline ManAg1 & $2.33 \pm 0.37 \mathrm{~b}$ & $0,91 \pm 0.05 \mathrm{ab}$ \\
\hline ManAg2 & $2.83 \pm 0.23 \mathrm{ab}$ & $0,95 \pm 0.01 \mathrm{ab}$ \\
\hline ManAg3 & $2.66 \pm 0.31 \mathrm{ab}$ & $0,90 \pm 0.04 \mathrm{~b}$ \\
\hline Statistical parameters & $F=2.821$ & $F=3.868$ \\
& $P=0.038$ & $P=0.01$ \\
\hline
\end{tabular}

In natural fallows land, the evolution of floristic richness was irregular. It has declined from Class 1 (64 species) to Class 2 (62 species); then, it has increased from Class 2 to Class 3, from 62 species to 76 species (Figure 1). In Acacia mangium fallows, floristic richness continuously increased with the age of fallow (Figure 1). The trend curve of the Shannon index according to the age of fallows showed opposite trends for the two types of fallows (Figure 2). Thus, while it decreases and then increases in natural fallows land, floristic diversity (expressed by the Shannon index) increased and then declined in fallows with Acacia mangium (Figure 2).

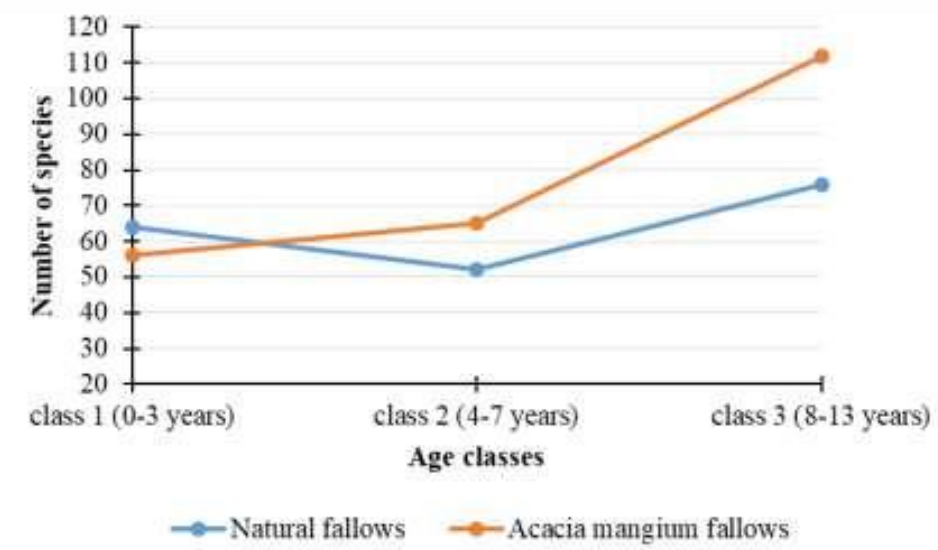

Figure 1 : Evolution curve of floristic richness on fallows studied 


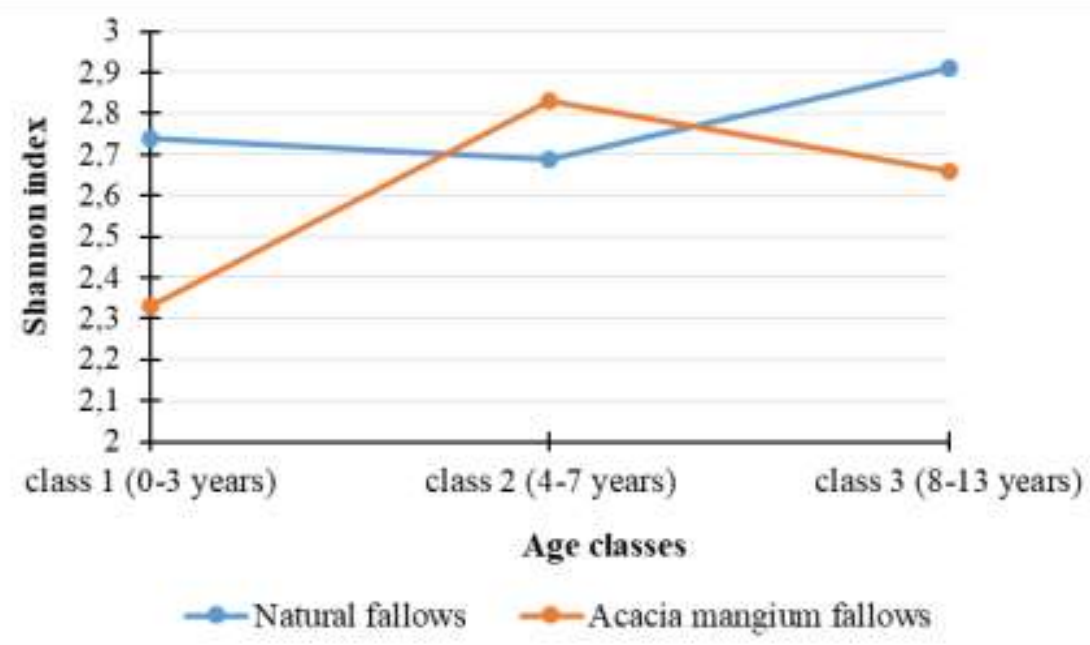

Figure 2 : Evolution curve of floristic diversity on fallows studied

\section{Floristic composition}

In Acacia mangium fallows, the current species were Baphia nitida, Dichapetalum pallidum, Microdesmis keayana, Icacina mannii, Salacia nitida, Cola heterophylla, Napoleonaea vogelii et Angylocalyx oligophyllus. In the natural fallow areas, Chromolaena odorata, Croton hirtus, Epinetrum cordifolium, Mariscus cylindrystachyus and Panicum maximum were the abundant species. Ligneous and lianas are the most common morphological types in Acacia mangium fallows, while herbaceous species are the dominant species of natural fallows (Table 3). Also, the proportions of herbaceous species decrease and those of ligneous increase as the fallows age (Table 3).

The statistical analysis revealed differences between averages of each morphological type in the different plots. Four groups of fallows are observed for ligneous (Table 3). In the first group, there was the parcels with the highest proportions of ligneous, namely ManAg1 (44.59 \pm 4.47$)$ and ManAg2 (52.70 \pm 4.47$)$. The latter group consists of the lowest proportions of ligneous, $\mathrm{Nat} A g 1$ (14.42 \pm 4.47$)$ and NatAg2 (14.61 \pm 4.47$)$. In the second and third groups, ManAg3 (37.04 \pm 4.47$)$ and NatAg3 $(18.12 \pm 4.47)$ there was the plots that proportions of ligneous are intermediate to those of the other two groups. The statistical differences between the proportions of lianas are characterised by five groups of biotopes (Table 3). In the first group, we find ManAg1 (40.84 \pm 3.58$)$ with the highest proportion. The second, third and fourth groups are ManAg3 (39.10 \pm 3.58$)$, ManAg2 (26.05 \pm 3.58$)$ and NatAg3 (24.12 \pm 3.58$)$. The latter group includes NatAg2 (18.13 \pm 3.58$)$ and NatAg1 (11.95 \pm 3.58$)$ which are the fallows with the lowest proportions of lianas. For herbaceous species, two groups of fallows are distinguished (Table 3 ). The first group contained the plots with the highest proportions of herbaceous. These are the

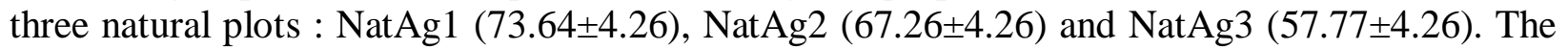


second group consists exclusively of Acacia mangium fallows with the lowest proportions of

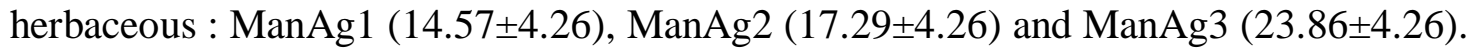

Table 3 : Proportions of morphological types

\begin{tabular}{|lllc|}
\hline & \multicolumn{3}{c|}{ Morphological types } \\
\cline { 2 - 4 } Fallows & Ligneous & Lianas & Herbaceous \\
\hline NatAg1 & $14.42 \pm 5.80 \mathrm{c}$ & $11.95 \pm 8.80 \mathrm{c}$ & $\mathbf{7 3 . 6 4} \pm \mathbf{5 . 7 4 a}$ \\
\hline NatAg2 & $14.61 \pm 8.10 \mathrm{c}$ & $18.13 \pm 3.65 \mathrm{c}$ & $\mathbf{6 7 . 2 6} \pm \mathbf{9 . 4 1 a}$ \\
\hline NatAg3 & $18.12 \pm 12.93 \mathrm{bc}$ & $24.12 \pm 5.67 \mathrm{bc}$ & $\mathbf{5 7 . 7 7} \pm \mathbf{1 3 . 0 4 a}$ \\
\hline ManAg1 & $\mathbf{4 4 . 5 9} \pm \mathbf{1 2 . 6 5 a}$ & $\mathbf{4 0 . 8 4} \pm \mathbf{8 . 2 2 a}$ & $14.57 \pm 12.30 \mathrm{~b}$ \\
\hline ManAg2 & $\mathbf{5 2 . 7 0} \pm \mathbf{4 . 1 7 a}$ & $26.05 \pm 10.61 \mathrm{abc}$ & $17.29 \pm 8.32 \mathrm{~b}$ \\
\hline ManAg3 & $37.04 \pm 12.43 \mathrm{ab}$ & $39.10 \pm 9.03 \mathrm{ab}$ & $23.86 \pm 5.62 \mathrm{~b}$ \\
\hline Statistical parameters & $F=14.015$ & $F=10.173$ & $F=39.483$ \\
& $P<0.0001$ & $P<0.0001$ & $P<0.0001$ \\
\hline
\end{tabular}

\section{Plant succession and floristic similarity}

The pioneering indices showed the the level of vegetation restoration in the different fallows. These indexes range from $153.86 \pm 6.19$ to $180.54 \pm 6.19$ in natural fallows, and from $77.31 \pm 6.19$ to $106.40 \pm 6.19$ in Acacia mangium fallows (Table 4). The statistical analysis indicates significant differences between the values of pioneer index in Acacia mangium fallows and those of natural fallows. The biotopes are separeted in four groups of (Table 4). The first group contains the biotopes with the highest pioneer indexes, NatAg1 (153.86 \pm 6.19$)$, NatAg2 (180.54 \pm 6.19$)$ and NatAg3 (167.96 \pm 6.19$)$. The second and third groups are plots with moderately high pioneer indexes. It respectively concerns ManAg3 $(106,40 \pm 6,19)$ and ManAg1 $(80,79 \pm 6,19)$. In the fourth and final group, we found the fallow with the lowest pioneer index, ManAg2 (77.31 \pm 6.19$)$. These results show that plant succession is more advanced in Acacia mangium fallows than natural fallows.

Except ManAg3 and NatAg1, the floras of natural fallows and Acacia mangium fallows were not similar. There were floristic similarities between fallows of same type (Table 5). The dendrogram derived from the hierarchical classification of the different plots revealed three groups of biotopes (Figure 3). These groups are constituted by NatAg2 and NatAg3 (Group 1), NatAg1 and ManAg3 (Group 2), ManAg1 and ManAg2 (Group 3). 
International Journal of Agriculture, Environment and Bioresearch

Vol. 4, No. 05; 2019

ISSN: $2456-8643$

Table 4 : Pionneer indexes on fallows studied

\begin{tabular}{ll}
\hline Fallows & Pionneer indexes \\
\hline NatAg1 & $153.86 \pm 13.54 \mathrm{a}$ \\
\hline NatAg2 & $180.54 \pm 2.50 \mathrm{a}$ \\
\hline NatAg3 & $167.96 \pm 14.08 \mathrm{a}$ \\
\hline ManAg1 & $80.79 \pm 17.47 \mathrm{bc}$ \\
\hline ManAg2 & $77.31 \pm 10.59 \mathrm{c}$ \\
\hline ManAg3 & $106.40 \pm 18.60 \mathrm{~b}$ \\
\hline Statistical parameters & $F=53.639$ \\
& $P<0.0001$ \\
\hline
\end{tabular}

Table 5 : Sorensen Matrix of Similarity on Fallows studied

\begin{tabular}{|c|c|c|c|c|c|c|}
\hline & ManAg1 & ManAg2 & ManAg3 & NatAg1 & NatAg2 & NatAg3 \\
\hline ManAg1 & 1 & 0.58 & 0.45 & 0.45 & 0.36 & 0.32 \\
\hline ManAg2 & & 1 & 0.47 & 0.38 & 0.36 & 0.31 \\
\hline ManAg3 & & & 1 & 0.56 & 0.39 & 0.40 \\
\hline NatAg1 & & & & 1 & 0.54 & 0.49 \\
\hline NatAg2 & & & & & I & 0.54 \\
\hline NatAg3 & & & & & & \\
\hline
\end{tabular}




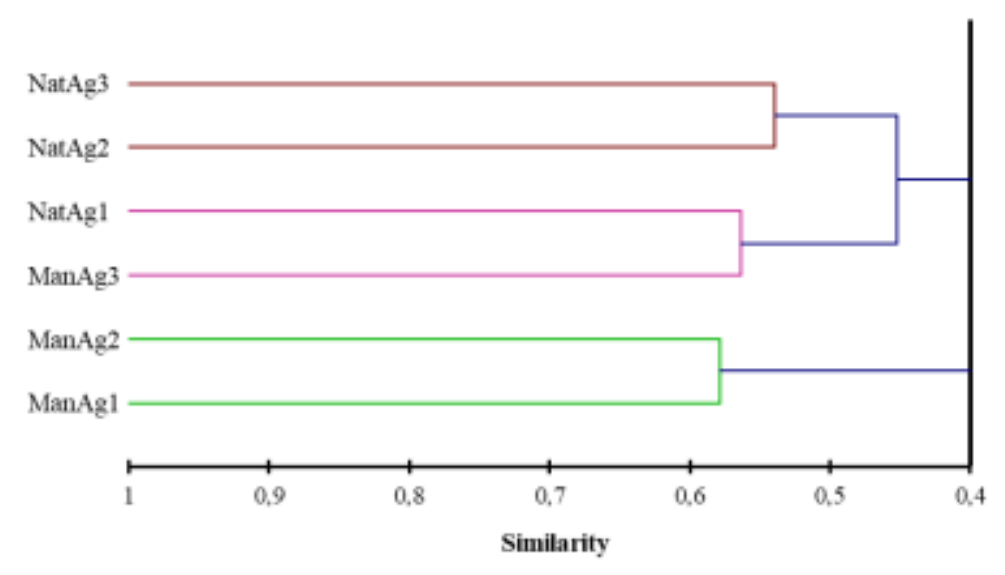

Figure 3 : Hierarchical clustering of fallows studied

\section{DISCUSSION}

The floristic richness is more important and grows faster in Acacia mangium fallows than natural fallows. The increase of specific richness reflects the succession of fallow stages that is marked at each stage by the appearance of new species (Kassi \& Decocq, 2007; Adingra \& Kassi, 2016). In natural fallows, herbaceous species predominate, while Acacia mangium fallows were dominated by tree species. According to Mitja (1992), competition from the herbaceous stratum in open and disturbed environments delays the recovery of ligneous flora. In addition, the abundance of annual species observed in natural fallows is a characteristic feature of fallows (Achard \& al., 2001). In fact, these species so-called pioneer species are able to colonize at first place and in quantity the cleared and abandoned environments. The relative presence of ligneous on Acacia mangium fallows is linked to the microclimate created by these legumineous trees, in particular by the vegetation cover and the physico-soil chemicals that promote the reconstitution of woody vegetation (Kouadio, 2018). In addition, the atmospheric nitrogen fixation contributes to the control of herbaceous flora which is harmful to the growth of woody flora (Harmand, 1998). There is a decrease in herbaceous proportions species and an increase in ligneous proportions as the age of fallows increases. These results are similar to those of the work on postcultural vegetation realised by Ntamwira \& Nyakabwa (2008) in the Democratic Republic of Congo and Bangirimana (2010) in Burundi. This observed trend characterises the progressive installation of a shrub stratum to replace the herbaceous stratum whose representatives are experiencing declines in proportions (Ayichedehou, 2000). However, the decline in floristic diversity and proportions of tree species in class 3 of Acacia mangium fallows is due to anthropogenic pressures, due to the maturity of some species. These pressures, characterized by the practice of bush fires, the collection of wood, woody fodder and medicinal plants, can disrupt 
Vol. 4, No. 05; 2019

ISSN: $2456-8643$

ecosystems and alter vegetation recovery processes (Floret \& Pontanier, 1993 ; Kassi \& Decocq, 2007).

Plant succession is initiated by pioneer species (pioneer stage), extended by heliophilic species (pre-climactic stage) and terminated by sciaphileous species that perform the climactic stage (Riéra \& al., 1990 ; Riéra, 1995). Thus, the strong pioneering indices observed on natural fallows mean that the plant succession is less advanced in natural fallows than ameliorated fallows. This observation demonstrates the advantage of tree fallow through the canopy to prevent the development of pioneer species. The lack of floristic similarity between natural fallows and Acacia mangium fallows reflects a difference in the reconstitution of biodiversity according to the type of fallow. Indeed, the stages of plant resilience depend on environmental conditions that give to fallows a multitude of morphological and floristic compositions (Fournier \& al., 2001). In addition, the possibilities for post-cultural succession depend on the related mechanisms and the ability to colonize and regenerate species such as reproductive biology, the presence of dormant seeds and vegetative reproductive or rejection organs, and modes of dissemination (Fournier \& al., 2001 ; Kabonyi \& al., 2014). Although it is a tree fallow, the class 3 of Acacia mangium fallow is floristically similar to class 2 of natural fallow. This can be explained by the anthropization of this parcel which created ecological conditions similar to those of natural fallow. This is confirmed by Bangirinama (2010) who showed that the similarity between sites is related to the ecological character of the environment and not to their age. For example, disturbances to fallows that result in habitat destruction and replacement with cultural vegetation may impede plant succession (Ayichedehou, 2000 ; Floret \& al., 2001). It therefore seems appropriate to abandon the fallows definitively so that it tends towards a forested stage and evolve into a ultimate stage forest (Serpantié \& Devineau, 1991 ; Bangirinama, 2010), because the return of shrubby or tree vegetation contributes to the increase in fertility (Kouadio, 2018).

\section{CONCLUSION}

This study revealed the ameliorating effect of Acacia mangium on floristic diversity. Unlike some introduced species which have proved invasive, Acacia mangium does not disturb the local flora. On the other hand, the presence of these tree legumineous trees allowed for advanced plant succession compared to natural fallow. Thus, regularly used for agricultural purposes, these legumineous trees appear as catalysts for forest resilience. The results of this work are an important asset for the prospects of forest vegetation restoration and sustainable forest management.

\section{REFERENCES}

Achard F., Hiernaux P. et Banoin M. (2001). Les jachères fourragères naturelles et améliorées en Afrique de l'Ouest. In : Floret C., Pontanier R. - La jachère en Afrique tropicale. John Libbey Eurotext, Paris, p. 201-239.

Adingra O.M.M.A. et Kassi J.N. (2016). Diversité floristique, structure et dynamique des jachères post-culturales de la forêt classée de Bamo (Côte d'Ivoire) Agr. Afric., 28 (1) : 24 - 32 
Allou K., Aké S., Ahoussou N., Ballo K. et Diabaté S. (2001). Effet de la jachère sur l'expression de la fusariose vasculaire du palmier à huile (Elaeis guineensis Jacq.). Agronomie Africaine. 13 (1) : 21-33.

Angiosperm Phylogeny Group. (2016). An update of Angiosperm Phylogeny Group classification for the orders and families of flowering- APG IV. Botan. J. Lin. Soc..; 181: 1-20.

Ayichedehou M. (2000). Phytosociologie, Écologie et Biodiversité des phytocénoses culturales et post-culturales du Sud et du Centre Bénin. Thèse de Doctorat, Université Libre de Bruxelles, Belgique, $282 \mathrm{p}$.

Bangirinama, F. (2010). Processus de la restauration écosystémiques au cours de la dynamique post-culturale au Burundi : mécanismes, caractérisation et séries écologiques. Thèse de doctorat, Université Libre de Bruxelles/Belgique.

Djaha B.A.O., Djaha J.B.A., N'Guessan A.K. et Traoré D. (2009). Impact des jachères à Légumineuses arborescentes sur la flore adventice au sud de la Côte d'Ivoire. Agronomie Africaine, 21 (2) : 143-154

Floret C. et Pontanier R. (1993). Recherches sur la dynamique de la végétation des jachères en Afrique tropicale. In : Floret C. \& Serpantié G. (Eds.). La jachère en Afrique de l'Ouest. ORSTOM, Paris: 33-46.

Floret C. et Pontanier R. (2000). La jachère en Afrique tropicale, 2 vol., vol. 1, Actes du séminaire international, Dakar, Sénégal, 13-16 avr. 1999, vol. II, De la jachère naturelle à la jachère améliorée: le point des connaissances, Paris, John Libbey, 804 p.

Fournier A, Floret, C. et Gnahoua, G-M. (2001).Végétation des jachères et succession postculturale en Afrique tropicale. In : Floret C., Pontanier R. La jachère en Afrique tropicale. John Libbey Eurotext, Paris, 123-168 p.

Harmand J.M. (1998). Rôle des espèces ligneuses à croissance rapide dans le fonctionnement biogéochimique de la jachère. Effets sur la restauration de la fertilité des sols tropicaux ferrugineux. Bois et Forêts des Tropiques, 256 (2) : 75-79.

Juhé-Beaulaton D. (2010). Forêts sacrées et sanctuaires boisés. Des créations culturelles et biologiques (Burkina Faso, Togo, Bénin), Paris, Karthala, 280 p.

Kabonyi N., Imani M., Munfano R., Mapendo N. \& Tautabazi F. (2014). Étude de la flore relique autours de Bukavu, Sud- Kivu (RDC). An.Univer.Goma, 5 : 166-182.

Kassi N.J. et Decocq G. (2007). Succession secondaire post-culturale en système forestier tropical semi-décidu de Côte d'Ivoire : approche phytosociologique intégrée et systémique. Phytocoenologia, 37 (2) : 175-219. 
Kouadio K.R. (2018). Effet des peuplements de trois légumineuses arborescentes (Acacia auriculiformis A. Cunn. ex Benth., Acacia crassicarpa Benth. et Acacia mangium Willd.) sur la diversité de la flore ligneuse spontanée de la forêt classée de l'Anguédédou en zone de forêt dense humide sempervirente (Côte d'Ivoire). Thèse unique de Doctorat, Spécialité Écologie Végétale, Université Nangui Abrogoua, Abidjan, Côte d'Ivoire, 173 p.

Mitja D. (1992). Influence de la culture itinérante sur la végétation d'une savane humide de Côte d'Ivoire (Booro-Borotou, Touba), Paris, Orstom, 270 p.

N'Goran A., Gnahoua G.M., Oualo K. et Balle P. (2002). Évolution du rendement du maïs après une jachère arborée en zone de forêt humide de Côte d'Ivoire. Cahiers Agricultures, 11 (2) : 145 149 .

N'Guessan K.A. (2006). Les légumineuses arborescentes, une alternative pour la régénération des jachères. Le cas de la zone forestière en Côte d'Ivoire. Thèse d'État ès Sciences Naturelles. Université de Cocody, Abidjan, Côte d'Ivoire, 157 p

Ntamwira N. et Nyakabwa M. (2008). Contribution à l'étude des groupements végétaux postculturaux de Burhinyi (Sud-Kivu, R.D. Congo) : I. L'association à Virectaria major (VirectarietummajorisHabiyaremye 1997). An. Scie., Université Officielle de Bukavu, Vol. 1 (1) : $57-62$

Riéra B. (1995). Rôle des perturbations actuelles et passées dans la dynamique et la mosaïque forestière. Revue d'Écologie (Terre Vie), $50: 209-222$.

Riéra B., Puig H. et Lescure J.P. (1990). La dynamique de la forêt naturelle. Bois et Forêts des Tropiques, 219: 69-78.

Serpantié G. et Devineau J.L. (1991). Le programme "interrelations systèmes écologiques systèmes de culture en zone soudanienne (ouest-burkinabé)" : projet scientifique. In : Floret C. \& Serpantié G. (Éds.). La jachère en Afrique de l'Ouest. ORSTOM, Paris, France : 481-490. 